\title{
Seroprevalence of Hepatitis A Virus in Children and Adults
}

\author{
Tekin Karsligil, Mervat Saeed*
}

Department of Medical Microbiology, Institute of Medical Sciences, University of Gaziantep, Gaziantep, Turkey

Copyright $\bigcirc 2018$ by authors, all rights reserved. Authors agree that this article remains permanently open access under the terms of the Creative Commons Attribution License 4.0 International License

\begin{abstract}
Hepatitis A is the most common form of acute viral hepatitis in the world. Major geographical differences in endemicity of hepatitis A are closely related to hygienic and sanitary conditions and other indicators of the level of socioeconomic development. In this study we aimed to investigate the seroprevalence of hepatitis A for adults and pediatric in university hospital- Gaziantep, and to demonstrate the relationship between various socio-demographic data and seropositivity. Serum samples were investigated by ELISA method for Anti HAV IgG and Anti HAV IgM. A total of 102 individuals, 55 male and 47 female, were included in the study. Anti HAV IgG positivity was detected in $87(85.3 \%)$, anti HAV IgM positivity was detected in $2(2.0 \%)$. There weren't any significant gender differences in HAV IgG. By analysis according to the age, Anti-HAV IgG seropositivity increased with age. Although there was no significant difference in HAV IgG seropositivity according to the types of drinking water supply, HAV IgG seropositivity was detected in a less percentage in individuals who drink the commercial water. In Turkey HAV infection has been shifted to older ages than younger age. The disease is more complicated in advanced age than younger people. We recommend the importance of applying the vaccine.
\end{abstract}

Keywords HAV, Seroprevalence, ELISA

\section{Introduction}

Hepatitis A is primarily seen all over the world and generally it is an extremely common childhood infectious disease. Although the asymptomatic high transmission rate of childhood, the incidence of symptomatic disease and complications such as fulminant hepatitis increases with age $[1,2]$.

Particularly, Hepatitis A is more common in the society where sanitary conditions and hygienic practices are unfavorable also people's economic and educational levels are poor. In high endemic areas, most children $90 \%$ have been infected with HAV before the age of 10 years. However, in developed communities with good sanitary and hygienic conditions infection rates shift to older age groups [3-4].

In a society, to identify the preventive measures of a disease such as hepatitis A which causes significant morbidity and mortality, it is important to determine the seroprevalence of this disease in the community and show the change in the seroprevalence over the years [1].

In this study we aimed to investigate the seroprevalence of hepatitis A for adults and pediatric in the University hospital - Faculty of medicine - Sahinbey - GaziantepTurkey, and to demonstrate the relationship between various socio-demographic data and seropositivity.

\section{Materials and Methods}

A total of 102 serum samples from adult and pediatric patients with age between 2-72 years old who have come to Gaziantep Sahinbey Research Hospital due to a variety of diseases between February 2014 and June 2014 were included in this study, The use of these specimens and data in research was approved by the Ethics Committee of the Faculty of Medicine of Gaziantep University.

In this study, anti-HAV IgG and IgM were investigated by the method of (ELISA) enzyme immunoassay assay (ACHITECT System -ABBOTT, Wiesbaden- Germany) in sera that obtained from the Microbiology department of University of Gaziantep Sahinbey Research Hospital. When the number of serum samples which stored in $-20 \mathrm{C}^{\circ}$ became sufficient, were examined according to manufacturer's recommendations. At the same time a variety of socio-demographics of the patients such as age, sex, vaccination history, place of living, drinking water supply, number of rooms in the house, number of individuals in the house, presence of chronic diseases, Jaundice story, and jaundice story in the family were also recorded to demonstrate the relationship between various socio-demographic data and seropositivity. 


\subsection{Kit Contents}

1- Microparticles

2- Conjugate

3- Assay diluent

4- Pre-trigger solution

5- Trigger solution

6- Wash Buffer

\subsection{Biological Principles of the Procedure}

The Architect HAVAb- IgG (the same procedure for $\operatorname{IgM})$ assay is a two-step immunoassay for the qualitative detection of IgG anti-HAV in human serum and plasma using (CMIA) technology with flexible assay protocols, referred to as Chemi-Flex. In the first step, sample, assay diluent and hepatitis A virus (human) coated paramagnetic Microparticles are combined. IgG anti-HAV present in the sample bindes to the hepatitis A virus (human) coated paramagnetic Microparticles. After washing, the anti-human IgG acridinium-labeled Conjugate that is added in the second step binds to IgG anti-HAV. Following another wash cycle, Pre-trigger and Trigger solutions are added to the reaction mixture. The resulting chemiluminescent reaction is measured as relative light units (RLUs). A direct relationship exists between the amount of IgG anti-HAV in the sample and the RLUs detected by the ARCHITECT System optics. The presence or absence of IgG anti-HAV in the sample is determined by comparing the chemiluminescent signal in the reaction to the cutoff signal determined from an ARCHITECT HAVAb- IgG calibration.

Specimens with signal to cutoff $(\mathrm{S} / \mathrm{CO})$ values $\geq 1$ are considered reactive for IgG anti-HAV.

Specimens with $(\mathrm{S} / \mathrm{CO})$ values $<1$ are considered (non-reactive) [1,5-7].

\subsection{Data Analysis}

In the analysis of the data obtained from the study SPSS 16.0 (Statistical Package for Social Sciences) Package Program was used. Percentage distribution and numbers were given as a descriptive statistics. Chi-square test (Cross tabs-Chi Square test) was applied to analyze the data and the obtained results were evaluated at significance level of $95 \%$.

\section{Results}

The findings obtained from the study are shown in the following tables to demonstrate the relationship between various socio-demographic data and seropositivity.

Of the individuals included in our study, 15 (14.7\%) have not been exposed to Hepatitis A virus and HAV IgG was negative [Table 1].

Table 1. Distribution of individuals according to HAV-IgG

\begin{tabular}{|c|c|c|}
\hline HAV-IgG & $\mathrm{n}$ & $\mathbf{( \% )}$ \\
\hline Negative & 15 & 14.7 \\
\hline Positive & 87 & 85.3 \\
\hline Total & 102 & 100.0 \\
\hline
\end{tabular}

Also HAV-IgM positivity was detected just only in $2(\% 2)$ while HAV-IgM was negative in $100(\% 98)$ of individuals [Table 2].

Table 2. Distribution of individuals according to the positive of HAV-IgM

\begin{tabular}{|c|c|c|}
\hline HAV-IgM & $\mathrm{n}$ & $(\%)$ \\
\hline Negative & 100 & 98.0 \\
\hline Positive & 2 & 2.0 \\
\hline Total & 102 & 100.0 \\
\hline
\end{tabular}

HAV IgM-positivity was detected in patients who have been admitted with complaint of jaundice and fatigue in the infection polyclinic, during the routine tests. ALT and AST tests of those patients were positive (normal value of ALT is 5-33, AST is 5-32 IU / L) [Table 3].

Table 3. Evaluation of patients with HAV-IgM positive

\begin{tabular}{|c|c|c|c|c|c|c|}
\hline & Jaundice & Fatigue & ALT(IU/L) & AST(IU/L) & Age & Gender \\
\hline 1- Patient & Yes & Yes & 946 & 529 & 23 & Female \\
\hline 2- Patient & Yes & Yes & 616 & 311 & 30 & Male \\
\hline
\end{tabular}

Statistically according to gender there was no significant difference in anti-HAV IgG positivity $(\mathrm{p}=0.542 ; \mathrm{p}>0.05)$ [Table 4]. 
Table 4. Comparison of HAV-IgG positivity according to gender

\begin{tabular}{|c|c|c|c|c|c|c|}
\hline & & \multicolumn{2}{|c|}{ HAV-IgG } & \multirow{2}{*}{ Total } & \multirow{2}{*}{$\chi^{2}$} & \multirow{2}{*}{$\mathrm{P}$} \\
\hline & Gender & Negative & Positive & & & \\
\hline \multirow[t]{2}{*}{ Female } & $\mathrm{n}$ & 8 & 39 & 47 & \multirow{4}{*}{0.373} & \multirow{4}{*}{0.542} \\
\hline & $\%$ & 17 & 83 & 100.0 & & \\
\hline \multirow{2}{*}{ Male } & $\mathrm{n}$ & 7 & 48 & 55 & & \\
\hline & $\%$ & 14.7 & 85.3 & 100.0 & & \\
\hline
\end{tabular}

Of 102 individuals included in the study, anti-HAV IgG seropositivity was (50\%) in the group that was up to 5, (64.7\%) in the group that was between 6 and $11,(100 \%)$ in groups of 12-18, 19-44, 45-64 years old, and (90\%) of adults (65 years old and over). Statistically there was significant difference in HAV IgG seropositivity according to age $(p<0.05)$ [Table 5]. The HAV IgG-negative person was 65 year old.

Table 5. Comparison of HAV-IgG positivity according to the age group

\begin{tabular}{|c|c|c|c|c|c|c|}
\hline & & \multicolumn{2}{|c|}{ HAV IgG } & \multirow{2}{*}{ Total } & $\chi^{2}$ & $\mathrm{P}$ \\
\hline \multicolumn{2}{|c|}{ Age } & Negative & Positive & & \multirow{13}{*}{24.235} & \multirow{13}{*}{0.000} \\
\hline \multirow{2}{*}{$0-5$ age } & $\mathrm{n}$ & 8 & 8 & 16 & & \\
\hline & $\%$ & 50.0 & 50.0 & 100.0 & & \\
\hline \multirow{2}{*}{ 6-11 age } & $\mathrm{n}$ & 6 & 11 & 17 & & \\
\hline & $\%$ & 35.3 & 64.7 & 100.0 & & \\
\hline \multirow{2}{*}{$12-18$ age } & $\mathrm{n}$ & 0 & 6 & 6 & & \\
\hline & $\%$ & 0 & 100.0 & 100.0 & & \\
\hline \multirow{2}{*}{ 19-44 age } & $\mathrm{n}$ & 0 & 32 & 32 & & \\
\hline & $\%$ & 0 & 100.0 & 100.0 & & \\
\hline \multirow{2}{*}{ 45-64 age } & $\mathrm{n}$ & 0 & 21 & 21 & & \\
\hline & $\%$ & 0 & 100.0 & 100.0 & & \\
\hline \multirow{2}{*}{$65 \&$ over age } & $\mathrm{n}$ & 1 & 9 & 10 & & \\
\hline & $\%$ & 10.0 & 90.0 & 100.0 & & \\
\hline
\end{tabular}

According to the number of individuals in the house, HAV IgG positivity was detected in $22(100 \%)$ when the number of individuals was 3 or less in the house, $34(75.6 \%)$ when the number of individuals was $4-5$ in the house and 31 ( $88 \%$ ) when the number of individuals was more than 5 in the house, thus statistically there was significant difference in HAV-IgG positivity among these groups $(\mathrm{p}<0.05)$ [Table 6].

Table 6. Comparison of HAV-IgG positivity according to the number of people in the house

\begin{tabular}{|c|c|c|c|c|c|c|c|}
\hline \multirow{8}{*}{$\begin{array}{c}\text { Number of persons in the } \\
\text { house }\end{array}$} & & & & & Totol & $x^{2}$ & $\mathrm{P}$ \\
\hline & & & Negative & Positive & & \multirow{7}{*}{7.824} & \multirow{7}{*}{0.020} \\
\hline & \multirow{2}{*}{$<=3$} & $\mathrm{n}$ & 0 & 22 & 22 & & \\
\hline & & $\%$ & $.0 \%$ & 100.0 & 100.0 & & \\
\hline & \multirow{2}{*}{$4-5$} & $\mathrm{n}$ & 11 & 34 & 45 & & \\
\hline & & $\%$ & $24.4 \%$ & 75.6 & 100.0 & & \\
\hline & \multirow{2}{*}{$\begin{array}{l}\text { More than } \\
\quad 5\end{array}$} & $\mathrm{n}$ & 4 & 31 & 35 & & \\
\hline & & $\%$ & $11.4 \%$ & 88.6 & 100.0 & & \\
\hline
\end{tabular}

Although statistical analysis showed there was no significant difference in HAV IgG seropositivity among groups according to drinking water supplies ( $\mathrm{p}>0.05)$, HAV IgG positivity was detected in $59(\% 89.4)$ of municipal water users, $20(\% 83.3)$ of purified water users and $8(\% 66.7)$ of commercial water users [Table 7$].$ 
Table 7. Comparison of HAV-IgG positivity according to the drinking water supply

\begin{tabular}{|c|c|c|c|c|c|c|c|}
\hline & & & \multicolumn{2}{|c|}{ HAV IgG } & \multirow{2}{*}{ Total } & \multirow{2}{*}{$\chi^{2}$} & \multirow{2}{*}{$\mathrm{P}$} \\
\hline & & & Negative & Positive & & & \\
\hline \multirow{6}{*}{ Drinking water supply } & \multirow{2}{*}{$\begin{array}{c}\text { Municipal } \\
\text { water supplies }\end{array}$} & $\mathrm{n}$ & 7 & 59 & 66 & \multirow{6}{*}{4.278} & \multirow{6}{*}{0.102} \\
\hline & & $\%$ & 10.6 & 89.4 & 100.0 & & \\
\hline & \multirow{2}{*}{ Purified } & $\mathrm{n}$ & 4 & 20 & 24 & & \\
\hline & & $\%$ & 16.7 & 83.3 & 100.0 & & \\
\hline & \multirow{2}{*}{ Commercial } & $\mathrm{n}$ & 4 & 8 & 12 & & \\
\hline & & $\%$ & 33.3 & 66.7 & 100.0 & & \\
\hline
\end{tabular}

On the other hand, statistical analysis conducted according to the number of rooms in the house indicated to Significant difference in HAV IgG positivity among groups $(\mathrm{p}<0.05)$. HAV IgG positivity was in $8(61.5 \%)$ of individuals where the house consists of two or less rooms, $40(87.0 \%)$ where the house consists of 3 rooms and $39(90.7 \%)$ where the house consists of more than 3 rooms [Table 8].

Table 8. Comparison of HAV-IgG positivity according to the number of rooms in the house

\begin{tabular}{|c|c|c|c|c|c|c|c|}
\hline & & & \multicolumn{2}{|c|}{ HAV IgG } & \multirow{2}{*}{ Total } & \multirow{2}{*}{$\chi^{2}$} & \multirow{2}{*}{$\mathrm{P}$} \\
\hline & & & Negative & Positive & & & \\
\hline \multirow{6}{*}{$\begin{array}{c}\text { Number of rooms in the } \\
\text { house }\end{array}$} & \multirow{2}{*}{$<=2$} & $\mathrm{n}$ & 5 & 8 & 13 & \multirow{6}{*}{19.588} & \multirow{6}{*}{0.000} \\
\hline & & $\%$ & 38.5 & 61.5 & 100.0 & & \\
\hline & \multirow{2}{*}{3 rooms } & $\mathrm{n}$ & 6 & 40 & 46 & & \\
\hline & & $\%$ & 13.0 & 87.0 & 100.0 & & \\
\hline & \multirow{2}{*}{ More than 3} & $\mathrm{n}$ & 4 & 39 & 43 & & \\
\hline & & $\%$ & 9.3 & 90.7 & 100.0 & & \\
\hline
\end{tabular}

While in evaluating the results of anti-HAV-IgG positivity shown in the table below according to the place of life. Statistically there was no significant difference between groups $(p=>0.05)$ [Table 9].

Table 9. Comparison of HAV-IgG positivity according to the living place

\begin{tabular}{|c|c|c|c|c|c|c|c|}
\hline & & & \multicolumn{2}{|c|}{ HAV IgG } & \multirow{2}{*}{ Total } & \multirow{2}{*}{$\chi^{2}$} & \multirow{2}{*}{$\mathrm{P}$} \\
\hline & & & Negative & Positive & & & \\
\hline \multirow{4}{*}{ Living place } & \multirow{2}{*}{ Urban areas } & $\mathrm{n}$ & 13 & 58 & 71 & \multirow{4}{*}{2.419} & \multirow{4}{*}{0.120} \\
\hline & & $\%$ & 18.3 & 81.7 & 100.0 & & \\
\hline & \multirow{2}{*}{ Rural areas } & $\mathrm{n}$ & 2 & 29 & 31 & & \\
\hline & & $\%$ & 6.5 & 93.5 & 100.0 & & \\
\hline
\end{tabular}

According to the HAV-vaccination, HAV-IgG positivity was detected in $20(76.9 \%)$ of vaccinated individuals, 34 $(82.9 \%)$ of non- vaccinated individuals and $33(94.3 \%)$ of individuals who didn't know. There was no significant difference among groups ( $\mathrm{p}>0.05)$ [Table 10]. Anti-HAV IgG was negative in $6(\% 23.1)$ from 26 vaccinated individuals.

Table 10. Comparison of HAV-IgG positivity according to the HAV-vaccination

\begin{tabular}{|c|c|c|c|c|c|c|c|}
\hline & & & \multicolumn{2}{|c|}{ HAV IgG } & \multirow{2}{*}{ Total } & \multirow{2}{*}{$\chi^{2}$} & \multirow{2}{*}{$\mathrm{P}$} \\
\hline & & & Negative & Positive & & & \\
\hline \multirow{6}{*}{ Vaccination } & \multirow{2}{*}{ No } & $\mathrm{n}$ & 7 & 34 & 41 & \multirow{6}{*}{3.892} & \multirow{6}{*}{0.143} \\
\hline & & $\%$ & 17.1 & 82.9 & 100.0 & & \\
\hline & \multirow{2}{*}{ Yes } & $\mathrm{n}$ & 6 & 20 & 26 & & \\
\hline & & $\%$ & 23.1 & 76.9 & 100.0 & & \\
\hline & \multirow{2}{*}{ Not knowing } & $\mathrm{n}$ & 2 & 33 & 35 & & \\
\hline & & $\%$ & 5.7 & 94.3 & 100.0 & & \\
\hline
\end{tabular}

HAV IgG positivity was in $18(94.7 \%)$ of 19 individuals included in our study with a history of jaundice while in 69 $(83.1 \%)$ of 83 individuals without history of jaundice, but there was no significant difference between groups ( $\mathrm{p}>0.05$ ) [Table 11].

Table 11. Comparison of HAV-IgG positivity according to the history of jaundice of the person

\begin{tabular}{|c|c|c|c|c|c|c|c|}
\hline & & & \multicolumn{2}{|c|}{ HAV IgG } & \multirow{2}{*}{ Total } & \multirow{2}{*}{$\chi^{2}$} & \multirow{2}{*}{$\mathrm{P}$} \\
\hline & & & Negative & Positive & & & \\
\hline \multirow{4}{*}{ History of jaundice } & \multirow{2}{*}{ No } & $\mathrm{n}$ & 14 & 69 & 83 & \multirow{4}{*}{1.660} & \multirow{4}{*}{0.198} \\
\hline & & $\%$ & 16.9 & 83.1 & 100.0 & & \\
\hline & \multirow{2}{*}{ Yes } & $\mathrm{n}$ & 1 & 18 & 19 & & \\
\hline & & $\%$ & 5.3 & 94.7 & 100.0 & & \\
\hline
\end{tabular}


Moreover HAV IgG positivity was higher (92\%) in individuals who have a family history of jaundice than individuals who do not (83.1\%), but there was no significant difference between those groups ( $>>0.05$ ) [Table 12].

Table 12. Comparison of HAV-IgG positivity according to the history of jaundice in the family

\begin{tabular}{|c|c|c|c|c|c|c|c|}
\hline & & & \multicolumn{2}{|c|}{ HAV IgG } & \multirow{2}{*}{ Total } & \multirow{2}{*}{$\chi^{2}$} & \multirow{2}{*}{$\mathrm{P}$} \\
\hline & & & Negative & Positive & & & \\
\hline \multirow{4}{*}{$\begin{array}{l}\text { History of jaundice in the } \\
\text { family }\end{array}$} & \multirow{2}{*}{ No } & $\mathrm{n}$ & 13 & 64 & 77 & \multirow{4}{*}{1.187} & \multirow{4}{*}{0.276} \\
\hline & & $\%$ & 16.9 & 83.1 & 100.0 & & \\
\hline & \multirow{2}{*}{ Yes } & $\mathrm{n}$ & 2 & 23 & 25 & & \\
\hline & & $\%$ & 8.0 & 92.0 & 100.0 & & \\
\hline
\end{tabular}

In evaluation of the results of anti-HAV-IgG positivity according to the association with chronic diseases, although anti-HAV-IgG positivity was higher in patients who have a chronic disease, a significant difference was not observed between groups $(\mathrm{p}=0,118)$ [Table 13].

Table 13. Comparison of HAV-IgG positivity according to the chronic disease

\begin{tabular}{|c|c|c|c|c|c|c|c|}
\hline & & & \multicolumn{2}{|c|}{ HAV IgG } & \multirow{2}{*}{ Total } & \multirow{2}{*}{$\chi^{2}$} & \multirow{2}{*}{$\mathrm{P}$} \\
\hline & & & Negative & Positive & & & \\
\hline \multirow{4}{*}{ Chronic disease } & \multirow{2}{*}{ No } & $\mathrm{n}$ & 10 & 39 & 49 & \multirow{4}{*}{2.445} & \multirow{4}{*}{0.118} \\
\hline & & $\%$ & 20.4 & 79.6 & 100.0 & & \\
\hline & \multirow{2}{*}{ Yes } & $\mathrm{n}$ & 5 & 48 & 53 & & \\
\hline & & $\%$ & 9.4 & 90.6 & 100.0 & & \\
\hline
\end{tabular}

\section{Discussion}

Viral hepatitis in both developed and developing countries continues to be a serious health problem. Hepatitis A infection at early ages is generally self-limiting, asymptomatic, rarely causes fulminant disease but does not become chronic. In developed countries, the disease shifts toward the elderly and the incidence of symptoms and complications of the disease increases in advanced ages. For this reason it is extremely significant to know the disease prevalence in the community to take protective measures. The prevalence of Hepatitis A infection varies among countries according to community hygiene, sanitary conditions and age groups, even between regions within the same country and over the years.

According to the age, HAV seroprevalence is observed in 3 different models: The first model; reflects the prevalence of hepatitis A in hyper-endemic developing countries. Infection usually occurs before the age of 10 , thus all adults have almost acquired natural immunity. Transmission is from person to person.

The second model; is in the moderate endemicity regions. Peak of the infection is in late childhood or adolescence. Transmission is from person to person and by food or water. Outbreaks are common .The third model; is seen in the closed community where the majority is susceptible to hepatitis A [1.8]. One of the three mentioned models is seen in the society. At the same time in different regions of the same country there are different prevalence rates which indicate to that living standards and environmental factors impact on the prevalence of HAV [8].

In our study, HAV IgG positivity was $85.3 \%$ in males and $83 \%$ in females. Studies conducted in Turkey and around the world have shown that HAV seroprevalence is similar in both sexes. In a study by Anahita Rabie et al. [9] that was done to investigate the seroprevalence of hepatitis A among enrolled students at the Tehran University of Medical Sciences in 2011, HAV IgG seropositive results were $(54 \%)$ for males compared to females (37\%).

In a study carried out by Almuneef Ma et al. [10] in Saudi Arabia for the 4-18 age groups, HAV IgG positivity was $29.5 \%$ in females and $28.2 \%$ in males. Also in a study carried out by Kanra et al. [11] the collected data from the various provinces in Turkey showed that HAV IgG positivity rate was $73 \%$ for females while $69.3 \%$ for males. In another study conducted in Trabzon, the total prevalence was found to be $47.1 \%$ [12]. In our study, HAV IgG positivity was $85.3 \%$ in males, and $83 \%$ in females.

Although the rates of various researches that were done in Turkey showed regional differences but were close to each other generally [Table 14]. 
Table 14. Studies conducted in various regions of Turkey

\begin{tabular}{|c|c|c|c|c|}
\hline study & Year & Region / City & Age group & Anti-HAVIgG Seropositivity (\%) \\
\hline Tekeli et al. [13] & 1991 & Ankara & $20-52$ & 99 \\
\hline Dündar et al. [14] & 1994 & Adana & 20 and over & 72.7 \\
\hline Cesur et al. [15] & 2001 & Ankara & $15-30$ & 71.3 \\
\hline Kanra et al. [11] & 2002 & 9 centers & under 30 & 92.5 \\
\hline Tosun et al. [16] & 2003 & İzmir & $15-45$ & 98.2 \\
\hline Arabacı and Oldacay [17] & 2009 & Çanakkale & $42-46$ & 96.8 \\
\hline Türker et al. [18] & $2004-2009$ & 4 centers & $20-60$ & 91 \\
\hline Altuntaş and ark. [19] & $2006-2011$ & Haseki & $27-49$ & 91.1 \\
\hline Tosun et al. [20] & $2007-2009$ & 4 centers & $1-80$ & 96.3 \\
\hline Tosun et al. [21] & 2011 & 10 centers & $23-51$ & 86 \\
\hline Çetinkol and Yıldırım [22] & 2011 & Ünye & $41-50$ & \\
\hline Karakaş et al. [23] & 2012 & Ankara & 25 and over & \\
\hline
\end{tabular}

In this context, regionally the evaluation of results obtained from our study showed a rate that was slightly higher than the results of studies carried out in western Turkey but seemed to be consistent.

Of 102 individuals included in our study, anti-HAV IgG seropositivity was detected in $8(50 \%)$ of the group that was up to 5 , and $11(\% 64.7)$ of the group that was between 6 and 11 years old, while anti-HAV IgG seropositivity was $(100 \%)$ in groups of $12-18,19-44,45-65$, and $(90 \%)$ of adults (65 years old and over). Consequently anti-HAV IgG seropositivity increased with age. Statistically there was significant difference in HAV IgG seropositivity according to age $(\mathrm{p}<0.05)$. In Iran in 2014 , the prevalence of HAV was $32 \%$ in less than $20,50 \%$ in $20-30$, and $67 \%$ in more than 30 years old [24]. Another study carried out in Chile in 2002, the HAV prevalence was overall determined $32.4 \%$. Also in the same time in this study, the HAV prevalence was $26.2 \%$ in the 5-9 age group, \%43.4 in the $10-14$ age group, $\% 57.4$ in the $15-19$ age group, and $73.9 \%$ in the 20-24 of age group [25]. Regarding the subject, a study conducted in UK on the seroprevalence of HAV that was $4 \%$ in the $1-4$ age group and $10.6 \%$ in the $5-14$ age group [26]. In a study conducted in Hong Kong, the seropositivity was $19.7 \%$ in the group that was under 30 years old while was $79.8 \%$ in the group that was over 30 years old [27]. In Izmir in a study conducted in 2008, HAV positivity was $4.6 \%$ in the $1-4$ age group, $23 \%$ in the $10-14$ age group and $\% 85$ in the 20-29 age group [28]. In a study conducted in Antalya, HAV seroprevalence was $19.9 \%$ in the $0-5$ age group, while was $43.9 \%$ in the $6-12$ age group [29]. In 2004 in Duzce, HAV seroprevalence was found to be $44.4 \%$ in the children aged $0-6$ years old [30]. Generally the results obtained in our study were consistent with the results obtained in previous studies.

Crowded living conditions facilitate the spread of hepatitis A. Particularly in institutions such as nursing homes, day-care centers, and barracks where prolonged grouping, rapid spread of such infections which fecal-oral transmitted occurs from person to person [8]. In a study conducted in 9 different provinces in Turkey, seropositivity was $80.1 \%$ in a large family where 6 or more individuals, while was $66.7 \%$ in families with 5 or fewer individuals [11]. A study that conducted by Atabek et al [31]. indicated to a significant relationship between HAV IgG positivity and crowded environments.

In our study according to the number of persons in the house HAV IgG positivity was $100 \%$ when the number of individuals was 3 or less in the house, $75.6 \%$ when the number of individuals was $4-5$ in the house and $88 \%$ when the number of individuals was more than 5 in the house, thus statistically there was significant difference among these groups. But of 22 who have lived in a house where 3 or less persons were, 4 individuals have been vaccinated, also 10 have chronic diseases (heart disease, diabetes, kidney disease). Since vaccinated people are already positive, the assessment should be based on 18 people. In addition, 10 individuals have chronic diseases, resulting in frequent visits to the hospital therefore should be expected to increase the probability of exposure of this group to the infection leading to a high seropositivity rate. In our study, although the rates were close to each other, correspond to the literature where the high seropositivity in large families.

Hepatitis A infection is commonly transmitted through contaminated food and drink. Water and food contaminated with fecal materials can lead to epidemics (1). Avoidance of mixing wastewater into drinking water is critical to prevent the transmission of hepatitis A, as well as adequate concentration of chlorine in drinking water to disrupt hepatitis A virus (1). In Chile a study carried out for a group of clean and safe drink water users, the seropositivity was significantly lower (5.5\%) [25]. In Konya in a study conducted by Atabek et al. the seropositivity in individuals with using water that is outside of drinking water was significantly higher [31]. In developed countries where robust infrastructure and clean 
drinking water supply, HAV infection shifts to an early age of adulthood. In studies regarding this subject, it has been reported that drinking water quality has a protective effect against infection [32]. Seroprevalence in our study according to the drinking water supplies where 3 groups determined (municipal water supply, filtered water and commercial water) was $89.4 \%, 83.3 \%, 66.7 \%$ respectively. Seropositivity was lower with using commercial water.

A variety of studies and a study conducted by Erdogan et al. [33] have reported the correlation between the significant increase of the seropositivity and the increase in the number of individuals per room.

In our study of 13 individuals where the house consists of 2 or less rooms, 46 individuals where the house consists of 3 rooms and 43 individuals where the house consists of more than 3 rooms, HAV IgG positivity was in $8(61.5 \%)$, $40(87 \%)$ and $39(90.7 \%)$ respectively. In this context it was observed that the results obtained from this study according to the number of rooms in the house were not consistent with literature. However, 6 out of 40 individuals where the house consists of 3 rooms, and 12 out of individuals where the house consists of more than 3 rooms, have reported that they had been given the HAV vaccine. In this case, it is considered to be the rate of positivity $61.5 \%, 73.9 \%, 62 \%$ in the individuals where the house consists of $\leq 2,3$ or more than 3 rooms respectively. There was no significant difference among these rates. This was because those individuals comply with the rules of sanitation or vaccination thus living in the immune family.

HAV IgG positivity in individuals included in our study and who have lived in rural areas was higher than those in urban areas, but the difference was not statistically significant. There are several studies that have investigated the anti-HAV seropositivity according to residential areas. In Konya in a study conducted by Atabek et al. [31] which was divided into two regions, there was significant difference of HAV seroprevalence between the two regions $87 \%-57.4 \%$ with a high seroprevalence in rural areas. In a study carried out by Erdogan et al. [33] in Edirne according to development and infrastructure status of the residential regions and divided into four groups, a significant high prevalence was found especially in the 2 regions with substructure problems. The study conducted in 2001 by Özkınay et al. [34] showed significantly higher rates in residents of the village. The results obtained from our study seemed to be compatible with the studies done before.

In our study anti-HAV IgG was negative in $6(\% 23.1)$ of 26 individuals who reported that they have received the HAV vaccine. All of these individuals were children between 1-5 years old ( 3 individuals were 5 , one 4 , one 2 and one 1 year old), the vaccine was reported by the families of these children, however they provided incorrect information, it is thought that it was due to the confusion with Hepatitis B vaccine. In addition, it is not known these children have immune suppression that increases susceptibility to large-scale infection. In a study conducted in 2009 in Shanghai, subjects aged 20-24 years had the lowest (34.4\%) anti-HAV seropositivity and subjects aged 5-9 years had the highest $(74.6 \%)$ positivity. Previous hepatitis A immunization policies had a significant impact on the presence of anti-HAV seroprevalence in a population aged 0-30 years from Shanghai [35]. In a study conducted in 2005 indicated to the absence of the immune response to vaccination against HAV in HIV-positive patients associated with the low of the CD4 cell count at the time of vaccination [36]. Therefore, it is thought that the sero-negativity in the persons, who have been naturally infected or given the vaccine, was associated with immunosuppression.

Hepatitis A infection passes and shows in different shapes, generally it is asymptomatic and diagnosed during screening. Many past researches demonstrated that there was a history of jaundice in many families. As a result of a study carried out by Akbak et al. [37] for children aged 1-15 years old, the history of jaundice was only detected in $19 \%$ of the anti-HAV-positive children. HAV IgG positivity was detected in $18(94.7 \%)$ of 19 individuals included in our study and with a history of jaundice while in $69(83.1 \%)$ of 83 individuals without a history of jaundice. There was no significant difference between groups. Also HAV IgG positivity was detected in $23(92 \%)$ of 25 individuals included in our study and with a family history of jaundice while in $64(83.1 \%)$ of 77 individuals without a family history of jaundice but a significant difference between these groups was not shown. A harmony was observed in the results obtained from our study comparing with the results obtained from previous studies regarding this subject.

In our study anti-HAV-IgG positivity was evaluated according to the situation of chronic diseases, anti-HAV-IgG positivity was detected in $39(79.6 \%)$ of those included in the study without suffering from any chronic diseases, while in $48(90.6 \%)$ individuals with suffering from chronic diseases such as kidneys, heart and diabetes diseases. Actually people who suffer from chronic diseases visit hospitals more than healthy people, so it can be considered that the risk of acquiring such infections rises in the hospital environment. However, there were no significant differences in anti-HAV-IgG positivity between these groups $(p=0.118)$.

\section{Conclusions}

It was observed that exposure to hepatitis A shifted towards older age in Turkey. In this study anti-HAV IgG seropositivity was $50 \%$ in individuals who were between 0-5 years old while $90 \%$ in individuals who were 65 years old or over. Immunization formed by vaccination, remains for 20 years, thus those vaccinated individuals will become unprotected after this period. Particularly those who have been immunized early in life and who believe they are protected from infection, will be exposed to infection at an advanced age. Complications and mortality 
caused by HAV infection are higher in elderly than younger people. Therefore we recommend that adolescents and persons within the risk groups to be evaluated for HAV infection and individuals who are susceptible to HAV infection to be vaccinated. In addition to, it is critical to comply with sanitation rules and maintain the daily chlorine residual and bacteriological control in the municipal water supplies regularly.

\section{REFERENCES}

[1] Wasley A, Feinstone S, Bell B. Hepatitis A Virus. Ġçinde: Mandell G, Bennett J, Dolin R. (ed). Mandell, Douglas, and Bennett's Principles and Practice Of Infectious Disease. Churchill Livingstone Elsevier. Philadelphia 7. ed. 2010. s: 2367-2387.

[2] Aygen B. Hepatit A Virüsü. Ed: Willke Topçu A, Söyletir G, Doğanay M: İnfeksiyon Hastalıkları ve Mikrobiyolojisi Cilt I., Nobel Tip Kitabevleri, İstanbul, 2002: 1340-1349.

[3] Steffen R. Hepatitis A in travelers: the European experience. Journal of Infectious Diseases 1995, 171(Suppl 1):24-28.

[4] Koff RS. Hepatitis A. Lancet, 1998; 341:1643-1649.

[5] Abbott. 2004. ARCHITECT System HAVAb-IgG: package insert. Abbott Diagnostics Division, Wiesbaden, Germany.

[6] Abbott. 2004. ARCHITECT System HAVAb-IgM: package insert. Abbott Diagnostics Division, Wiesbaden, Germany.

[7] Anderson, D. A. 2007. Hepatitis A and E Viruses, p. 1424-1436. In Murray, P. R., Baron, E. J., Jorgensen, J. H., Landry, M. L., and Pfaller, M. A. Manual of Clinical Microbiology, 9th ed., vol. 2. ASM Press, American Society for Microbiology, Washington, DC.

[8] Akbulut A. HAV İnfeksiyonu. Ed: Tekeli E, Balık İ: Viral Hepatit 2003. Roche, İstanbul, 2003;57-84.

[9] Anahita Rabiee, Sina N, Seyed R H, Mostafa M, Marzieh A, Roozbeh R, Shahin M, Seroprevalence of Hepatitis A among Students Enrolled in Tehran University of Medical Sciences during 2011.Middle East journal of Digestive diseases.jul 2013; 5(3) 137.

[10] Almuneef MA, Memish ZA, Balkhy HH, Qahtani M, Alotaibi B, Hajeer A, Qasim L, Knawy BA. Epidemiologic shift in the prevalence of Hepatitis A virus in Saudi Arabia: A case for routine Hepatitis A vaccination. Vaccine, 2006;24:5599-5603.

[11] Kanra G, Tezcan S, Badur S; Turkish National Study Team. Hepatitis A seroprevalence in a random sample of the Turkish population by simultaneous EPI cluster and comparison with surveys in Turkey. Turk J Pediatr 2002;44 (3):204-210

[12] Baki A, Aynacı M, Köksal I. Prevalence of antibody to hepatitis A virus among children in Trabzon. Infection 1993; 21(2): 132-133

[13] Tekeli E, Wilke A, Balık A. Kan vericilerin serumlarında hepatit A virus antikorlarının araștırılması. 3. Ulusal Enfeksiyon Hastalıkları Kongresi 22-26 Nisan 1991; Sorgun, Antalya. Kongre Kitab1 1991;330-1

[14] Dündar İH, Yaman A, Çetiner S, Kılıç NB, Apan TZ. Kan Donörlerinde ve Random Seçilmiş Hasta Örneklerinde Muhtelif Hepatit Markerlerinin Sıklığı. Türk Mikrobiyoloji Cemiyeti Derg. 1994; 24: 236-9.

[15] Cesur S, Akin K, Dogaroglu I, Birengel S, Balik I: Hepatitis A and hepatitis E seroprevalence in adults in the Ankara area. Mikrobiyol Bul. 2002;36(1):79-83.

[16] Tosun YS, Özacar T, Zeytinoğlu A, Tavmergen E, Bilgiç A. Infertilite olgularında hepatit $\mathrm{A}$, hepatit $\mathrm{B}$ ve hepatit $\mathrm{C}$ seroprevalans1. Medical Network Klinik Bilimler ve Doktor. 2003; 9(2): 215-9.

[17] Arabac1 F, Oldacay M. The seroprevalance of Hepatitis A in Different Age Groups and Hepatitis A Incidence in Acute Hepatitis Cases in The Çanakkale Province. J Pediatr İnf. 2009;3: 58-61.

[18] Türker K, Oğan CH, İskender G, Erbay Ç, Balcı E, Hasçuhadar M, Yeşilyurt H. Günümüz Türkiye'sinde Hepatit A Kronik Viral Hepatitlerde Gerçek Bir Sorun mudur? X.Ulusal Viral Hepatit Kongre Kitab1. Antalya, $2010 ; 167$.

[19] Altuntaş AÖ, Kumbasar KH, Korkusuz R, Ataoğlu HE, Nazlican Ö. HIV/AIDS Hastalarında HAV lgG Seroprevalansı. XI. Ulusal Viral Hepatit Kongre Kitabı. Antalya, 2012; 84-85.

[20] Tosun S, Ayaz H, Deveci S, Aksu S. Çocuk ve Erişkinlerde Hepatit A Virusu ile Karşılaşma Durumunun Değerlendirilmesi. X.Ulusal Viral Hepatit Kongre Kitabı. Antalya, 2010; 121.

[21] Tosun S, Yıldız O, Tekinkoruk S, Celen MK, Yılmaz G, Karabay O, Asan A, Evirgen Ö, Sünbül M, Yalçı A, Balık I, Tabak F. Kronik HBV ve HCV Olgularının HAV ile Karşılaşma Durumlarını Yeterince Değerlendiriyor muyuz? XI. Ulusal Viral Hepatit Kongre Kitab1. Antalya, 2012; $80-81$.

[22] Çetinkol, Y., Yıldırım, A.A. Ünye Devlet Hastanesine Başvuran Hastalarda Hepatit A Seroprevalans1. The Medical Journal of Kocatepe. 2011;12: 18-22.

[23] Karakaş A, Coşkun Ö, Mert G, Gül HC, Avcı IY, Eyigün CP. Hepatit A Seroprevalansında Yedi Yılda Ne Değiști? XI. Ulusal Viral Hepatit Kongre Kitab1. Antalya, 2012; 52

[24] Ziba Farajzadegan, Shervin Ghaffari Hoseini, Roya Kelishadi, Fahimeh Jamshidi, Zari Nokhodian, Rasool Noori, Parisa Mirmoghtadaee, Silva Hovsepian, Seyyed-Nassereddin Mostafavi. Systematic review and meta-analysis on the age-specific seroprevalence of hepatitis A in Iran. J Res Med Sci. 2014 Mar; 19(Suppl 1):S56-63

[25] Fix AD, Martin OS, Gallicchio L, Vial PA, Lagos R: Age-specific prevalence of antibodies to hepatitis A in Santiago, Chile; risk factors and shift in age of infection among children and young adults. Am J Trop Med Hyg 2002; 66(5):628-632

[26] Roberts RJ, Palmer SR: Exposure to school children as a risk factor in a community outbreak of hepatitis A in young adults: a case control study Epidemiol. Infect., 1-5 Cambridge University Press 
doi:10.1017/S0950268805005625 Printed in the United Kingdom 2005262 1998. 8:65-67 2000.

[27] Wong KH, Liu YM, Ng PS, Young BW, Lee SS: Epidemiology of hepatitis A and hepatitis E infection and their determinants in adult Chinese community in Hong Kong. J Med Virol. 2004; 72 (4):538-544.

[28] Kurugol Z, Aslan A, Turkoglu E, Koturoglu G. Changing epidemiology of hepatitis A infection in Izmir, Turkey. Vaccine. 2011 Aug 26; 29 (37):6259-61. doi: 10.1016/j.vaccine.2011.06.069. Epub 2011 Jul 18.

[29] Çolak D, Öğünç D, Günseren F, Velipaşaoğlu S, Aktekin MR, Gültekin M. Seroprevalance of antibodies to hepatitis $\mathrm{A}$ and $\mathrm{E}$ viruses in pediatric age groups in Turkey. Acta Microbiol Immunol Hung 2002; 49 (1): 93-7.

[30] Şencan I, Şahin I, Kaya D, Öksüz S, Yıldırım M. Assessment of HAV and HEV seroprevalance in children living in post-earthquake camps from Duzce, Turkey. Eur J Epidemiol 2004; 19 (5): 461-5.

[31] Atabek ME, Findık D, Gulyuz A, Erkul I. Prevalence of anti-HAV and anti-HEV antibodies in Konya, Turkey. Health Policy; Mar; 67 (3):265-269 2004.
[32] Barzaga NG. Hepatitis A shifting epidemiology in South-East Asia and China. Vaccine 2000;18(Suppl 1):S61-S64.

[33] Erdogan MS, Otkun M, Tatman-Otkun M, Akata F, Ture M: The epidemiology of hepatitis a virus infection in children, in Edirne, Turkey. Eur J Epidemiol.; 19(3):267-273 2004.

[34] Özkınay F, Kurugöl Z, Koturoglu G ve ark. İzmir'de farklı yaş gruplarında hepatit A prevalansı ve sosyoekonomik faktörlerle ilişkisi. Adana II. Ulusal Çocuk İnfeksiyon Hastalıklar1 Kongresi Kongre kitab1 2001, Adana: 50-52.

[35] Zhu Y, Yuan Z, Zhao Q, Chen G, Xu B. Seroprevalence of hepatitis A virus antibody in a population aged 0 -30 years in Shanghai, China: implications for hepatitis A immunization. Epidemiol Infect. 2013 Mar; 141(3):556-62. Epub 2012 Jun 12.

[36] Rimland D1, Guest JL.Response to hepatitis A vaccine in HIV patients in the HAART era. AIDS. 2005 Oct 14;19(15):1702-4

[37] Akbak M. Çocukluk yaş grubunda hepatit A, B, C, D seroprevalansı, risk faktörleri, bulaşma yolları ve HBV seropozitifçocuklarda aile taraması. Uzmanlık Tezi, 1996, Ankara 